11. Palti, J. Acta phytomed. 6, 11 (1978).

12. Cohen, H. \& Neish, G. at New Compounds in Biological and Chemical Warfare: Toxicological Evaluation, Ghent 21-23 May 1984.

13. Greenhalgh, R., Miller, J.D., Neish, G. \& Schiefer, H.B. at New Compounds in Biological and Chemical Warfare. Toxicological Evaluation, Ghent 21-23 May 1984.

14. Rosen, J.D. Science 221, 698 (1983).

15. Ashton, P.S., Meselson, M., Robinson, J.P.P. \& Seeley, T.D. Science 222, 366-368 (1983)

16. Ashton, P.S., Meselson, M., Nowicke, J.W., Robinson, J.P. \& Seeley, T.D. at A. Mect. Am. Ass. Advan. Sci. Detroit 31 May 1983.

\section{Climatic effects of Volcanic eruptions}

SIR - The appropriateness of using volcanic eruptions as a basis for estimating the climatic effects of nuclear war has recently been discussed ${ }^{1-5}$. Generally speaking, the relatively small quantities of aerosols produced by historic eruptions and the differences in the optical properties between volcanic aerosols $\left(\mathrm{H}_{2} \mathrm{SO}_{4}\right.$ and fine ash) and the sooty smoke from fires generated by nuclear blasts make any comparisons between the atmospheric after-effects of historic eruptions and nuclear war tenuous ${ }^{1,2}$. In other instances, namely those of the largest-scale eruptions, volcanic analogies may be relevant.

The greatest known Quaternary explosive eruption was the Toba (Indonesia) outburst of 75,000 years ago, which erupted approximately $1,000 \mathrm{~km}^{3}$ of rhyodacitic magma in perhaps 9 to 14 days $^{6,7}$. The widespread Toba ash layer is found over at least $5 \times 10^{6} \mathrm{~km}^{2}$ (ref. 6), but the total amount of long-lived stratospheric $\mathrm{H}_{2} \mathrm{SO}_{4}$ aerosols produced by this eruption is not known. We may, however, make some estimate of this quantity by using data from more recent eruptions of comparable magma type ${ }^{8}$. The sulphuric acid aerosols generated by the small $1980 \mathrm{Mt}$ St Helens eruption, which produced $0.35 \mathrm{~km}^{3}$ of dacitic magma, totalled $-3 \times 10^{11} \mathrm{~g}$. If the Toba eruption released a proportionate amount of $\mathrm{H}_{2} \mathrm{SO}_{4}$ aerosols, the stratospheric loading after that event could have been $-9 \times 10^{14} \mathrm{~g}$. On the other hand, if the Toba sulphur release was proportional to the output from the 1883 Krakatau eruption, which released a relatively larger percentage of sulphur volatiles, $5 \times 10^{13} \mathrm{~g}$ of $\mathrm{H}_{2} \mathrm{SO}_{4}$ aerosols from $10 \mathrm{~km}^{3}$ of dacitic magma ${ }^{8}$, then the stratospheric loading could have been as great as $5 \times 10^{15} \mathrm{~g}$. (Questions regarding rates of aerosol nucleation, saturation, and fallout in a very dense stratospheric aerosol cloud are currently being studied.) Distributed worldwide, these aerosol mass loadings are equivalent to globally averaged peak optical depths of 6 and 33, respectively ${ }^{9}$; regionally, the optical depths could have been even greater. An aerosol optical depth of 6 would have had at least a moderate climatic impact ${ }^{9}$ while an aerosol optical depth of 33 is equivalent to the smoke optical depths used in all but the most severe nuclear winter scenarios ${ }^{1,2}$.

Basaltic volcanic eruptions may release even greater percentages of sulphur volatiles ${ }^{10,11}$. Moreover, observations and recent calculations suggest that large, generally effusive, fissure basaltic eruptions can produce widespread highaltitude aerosols, possibly from convective plumes rising above vigorous fire fountains ${ }^{10-13}$. A good example of the product of a large basaltic eruption is the massive Roza lava flow (age $~ 14 \mathrm{Myr}$ ) of the Columbia River Basalt Group ${ }^{14}$. It is calculated that this single eruption produced more than $700 \mathrm{~km}^{3}$ of basalt lava (covering an area of $40,000 \mathrm{~km}^{2}$ ) in as little as 7 days. The greatest basalt eruption in recent historical times, the Laki (Iceland) fissure eruption ${ }^{10}$ of 1783 (volume $-12 \mathrm{~km}^{3}$ ) is estimated to have generated about $1 \times 10^{14} \mathrm{~g}$ of $\mathrm{H}_{2} \mathrm{SO}_{4}$ aerosols ${ }^{8}$. Therefore, the production from the 60 times greater Roza event could have been $-6 \times 10^{15} \mathrm{~g}$, or enough to give a globally averaged aerosol optical depth of about 40 . This is equivalent to a smoke optical depth of the size assumed in the most severe nuclear winter models ${ }^{1,2}$.

Did these eruptions cause sudden and sharp climate cooling? The Toba eruption does coincide with a time of falling global temperatures ${ }^{15}$, and there is also some evidence of global environmental changes at the time of the Columbia River Basalt eruptions (mostly between 17 and $14 \mathrm{Myr}$ ago) ${ }^{16,17}$ and at times of other flood basalt extrusions ${ }^{11,13}$. However, more detailed studies are required to determine whether these coolings were related to the volcanic eruptions, and to assess just how severe the climatic effects of these eruptions really were.

MiCHAEL R. RAMPINO RICHARD B. STOTHERS

NSA Goddard Space Flight Center, Institute for Space Studies,

New York,

New York 10025, USA

\section{STEPHEN SELF}

Department of Geology,

University of Texas at Arlington, Arlington, Texas 76019, USA

1. Turco, R.P., Toon, O.B., Ackerman, T., Pollack, J.B. \& Sagan, C. Science 222, 1283-1300 (1983).

2. Turco, R.P. et al. Scient. Am. 251, (2), 33-43 (1984).

3. Maddox, J. Nature 307, 107 (1984)

4. Bown, W.H.; Peczkis, J. Nature 310, 455 (1984)

5. Turco, R.P. et al.; Maddox, J. Nature 311, 307-308 (1984).

6. Ninkovich, D., Sparks, R.S.J. \& Ledbetter, M.T. Bull. Ninkovich, D., Sparks,
Volcan. 41, 1-13 (1978).

. Ninkovich, D., Shackleton, N.J., Abdel-Monem, A.A. Obradovich, J.D. \& Izett, G. Nature 276, 574-577 (1978).

8. Rampino, M.R. \& Self, S. Nature 310, 677-679 (1984).

9. Stothers, R.B. Nature 307, 344-345 (1984); Science 224, 1191-1198 (1984)

10. Sigurdsson, H. Eos 63, 601-602 (1982)

11. Devine, J.D. Sigurdsson, H., Davis, A.N. \& Self, S. J geophys. Res. 89, 6309-6325 (1984).

12. Wood, C. Eos 65, 410 (1984)

13. Wolff, J.A., Self, S., Rampino, M.R. \& Stothers, R.B. Eos 65, 1148-1149 (1984).

14. Hooper, P.R. Science 215, 1463-1468 (1982)

15. Rampino, M.R., Self, S. \& Fairbridge, R.W. Science 206, 826-829 (1979).

16. Woodruff, F., Savin, S.M. \& Douglas, R.G. Science 212 665-668 (1981)

7. Axelrod, D.I., Geol. Soc. Am. Spec. Pap. 185, 1-59 (1981).

\section{Basement membrane nomenclature}

SIR - In a recent issue of Nature, Bluemink et al. ${ }^{1}$ correctly pointed out the confusion existing over the nomenclature of basement membranes, but their recommendations are not in accord with usage by British, North American, French and Japanese scientists. The International Anatomical Nomenclature Committee ${ }^{2}$ recently recommended the following names for the successive layers of basement membranes: (1) "lamina lucida", the pale layer in immediate contact with the plasmalemma of the associated epithelial or other cells; (2) "lamina densa", the dark layer below; and (3) "lamina fibroreticularis", the incomplete layer (sometimes missing) in continuity with connective tissue. This classification is justified by the fact that the specific components of basement membrane (type IV collagen, laminin and heparan sulphate proteoglycan $^{3-5}$ ) are present in the three layers and little or none is found elsewhere. Thus, the three substances are abundant in the lamina densa, forming closely packed cords; they are present in lesser amounts in the lamina lucida as a few loosely arranged cords ${ }^{6}$ and they may occur in the lamina fibroreticularis within "bridges" connecting with other basement membranes (unpublished).

One confusion in the literature is the ambiguity of the term "basal lamina", which many histologists have used in the past to describe the "lamina densa", while others consider "basal lamina" synonymous with "basement membrane". As more is learned of the composition ${ }^{3,6,7}$, synthesis $^{3,7}$, structure ${ }^{8}$ and function ${ }^{4}$ of basement membranes, it is important that the terminology be unambiguous. We have adopted the terms defined in the guidelines of the International Anatomical Nomenclature Committee ${ }^{2}$, and urge others to do so.

\section{Laboratory of Developmental Biology} and Anomalies,

National Institute of Dental Research, National Institutes of Health, Bethesda, Maryland 20205, USA

\section{C.P. LEBLOND}

Department of Anatomy,

McGill University,

3640 University Street,

Montreal, Quebec, Canada H3A $2 B 2$

Bluemink, J.G., Faber, J. \& Lawson, K.A. Nature 312, 107 (1984)

'Nomina Histologica' in Nomina Anatomica, st Edn.(Williams and Wilkins, Baltimore, 1983).

Timpl, R. \& Martin, G.R. in Immunochemistry of the Extracellular Matrix Yol. 2. (ed. Furthmayr, H.) 119-150 (CRC Press. Boca Raton, Florida, 1982).

4. Farquhar, M.G. in Cell Biology of Extracellular Matrix (ed. Hay E.D.) 335-378 (Plenum, New York, 1981)

. Kleinman, H.K. et al. Biochemistry 24, 6188-6193 (1982)

6. Laurie, G.W., Leblond, C.P., Inoue, S., Martin, G.R. \& Chung, A. Am. J. Anat. 169, 463-481 (1984).

Kefalides, M A. Alper, R. \& Clark, C.C. Int Rev. Cytol. 61, 167-228 (1979)

8. Inoue, S., Leblond, C.P. \& Laurie, G.W. J. Cell Biol. 97 1524-1537 (1983). 